\title{
DEMOGRAPHIC FEATURES AND COMMON PRESENTATIONS OF SCHIZOPHRENIA
}

\author{
Ahammad JU' ${ }^{1}$, Rahman $\mathrm{MH}^{2}$, Islam $\mathrm{MA}^{3}$, Rahman $\mathrm{MS}^{4}$, Rabbani $\mathrm{MG}^{5}$.
}

\begin{abstract}
Fifty cases of schizophrenia were assessed in Combined Military Hospital (CMH), Dhaka and National Institute of Mental Health (NIMH), Sher-eBangla Nagar, to ascertain the pattern of demographic features and symptom presentation in current national perspective. The study includes period from July 2004 to September 2005. Most of the patients belonged to the age ranging from 14 to 45 years throughout whole Bangladesh. It was found that $54 \%$ of the patients were male and $46 \%$ were female. The lowest age of onset was $\mathbf{1 4}$ year for both sexes and the highest age of onset was 45 year in female and 41 years in male. Among the schizophrenic patients $\mathbf{5 0 \%}$ were unmarried and $50 \%$ were married and most of them belonged to lower economic class.

In this study both the urban and rural percentage were equal $(50 \%)$. Most of the patients were unemployed or recently disengaged from work place with a lower educational back ground. The most frequent patterns of symptom irrespective of demographic variables were persecutory ideas or delusion (76\%). Analysis revealed that delusion of reference, grandiose delusions, delusion of control or possession of thought were significantly high among the male patients compared to female patients $(\mathbf{p}<\mathbf{0 . 0 5})$, but no statistically significant difference was observed with other symptoms $(p>0.05)$. Analysis found that no statistically significant difference was observed between urban and rural patients $(p>0.05)$ except visual and other hallucinations e.g. gustatory, olfactory which was significantly high among the urban patients $(p<0.05)$. The next frequent symptom was perceptual disturbances in the form of auditory hallucination $\mathbf{( 7 0 \% )}$. Delusion of reference was about $70 \%$ along with delusion about control or possession of thoughts being approximately $42 \%$.
\end{abstract}

Key Words: Demographic features, Common presentations, Schizophrenia.

\section{Introduction}

Schizophrenia is the most severe and costliest medical condition of variable but profoundly disruptive psychopathology which involves thought, perception, behavior, emotion and movement ${ }^{1}$. The expression of those manifestations varies across patients and over time, but the effect of the illness is always severe and is usually long lasting. It is a chronic, debilitating psychotic major mental disorder that affects one percent of population ${ }^{2}$. A new generation of medications and recent developments in neuropathology, brain imaging and molecular genetics, viral and immunological models of causation have led to a greater understanding of the pathophysiological and treatment aspects of schizophrenia ${ }^{3}$. Schizophrenia is a disturbance that last for at least 6 months and includes at least one month of active phase symptoms unless successfully treated and must result in significant impairment of social and occupational functioning ${ }^{4}$. This study emphasizes the implication of the sociodemograpic data along with pattern of symptom presentation of schizophrenia in Bangladeshi cultural back ground.

\section{Materials and Methods}

This cross sectional study was carried out covering a total of fifty patients conducted in psychiatry department of Combined Military Hospital (CMH), Dhaka and National Institute of Mental Health (NIMH), Sher-e-Bangla Nagar during the period of July 2004 to September 2005.

Study instruments

i) Semi structured questionnaire.

ii) Non-patient version of structured clinical interview for diagnosis (SCID).

iii) Diagnosis of schizophrenia were confirmed by using diagnostic and statistical manual (DSM-iv) of mental disorders.

Inclusion criteria included

i) First episode cases of schizophrenia attending $\mathrm{CMH}$ Dhaka irrespective of sex and age.

ii) First episode of schizophrenia attending NIMH Sher-eBangla Nagar irrespective of sex and age.

iii) First time and consecutively attending $\mathrm{CMH}$ and NIMH Dhaka fulfilling DSM-iv operational criteria.

Exclusion criteria included

i) Patients who were mute, stuporous and non communicable.

ii) Patient suffering from cognitive disorder and severe medical illnesses.

iii) Patient with history of substance related disorder.

iv) Those psychotic cases attributable to organic disorder.

\section{Results}

In examining the socio-demographic correlates in table-I, it was clear that $60 \%$ of the patients were between 16 to

1. Maj Julhash Uddin Ahammad, FCPS, Graded Specialist in Psychiatry, CMH Bogra, 2. Lt Col Md Habibur Rahman FCPS, Department of Psychiatry, CMH, Dhaka, 3. Lt Col Md Azizul Islam FCPS, Department of Psychiatry, AFMC 4. Brig Gen M Sajjadur Rahman, FCPS, Professor and Head, Psychiatry, AFMC, 5. Maj Gen MG Rabbani FCPS, Consultant Physician General, Bangladesh Armed Forces. 
29 years of age and only $8 \%$ of the patients were at or above the age of 40 year. The sex ratio was approaching relatively equal in that male sex constituting $54 \%$ in comparison to $46 \%$ female sex. There were equal percentages of married and unmarried patients. $90 \%$ of the patients were Muslim compared to $10 \%$ non-Muslim which included mostly Hindus. Schizophrenia affected both the illiterate and literate group which included primary, secondary and higher level constituting more than $90 \%$ of the patients. Among different social classes middle class was leading as highest percentage (42\%). The percentage of unemployed $(72 \%)$ was more than that of employed (28\%).

Table-II shows that among the deferent symptoms persecutory delusions were highest $(76 \%)$ in all age groups and it was the highest $(80 \%)$ in the age group of 16-29 years. Somatic delusions were lowest (08\%) amongst symptoms. Delusion of reference was $70 \%$. Auditory hallucination also constitutes 70\%. Delusion about control or possession of thought constitutes $42 \%$. Visual or other hallucinations were $50 \%$. Grandiose delusion was observed among $10 \%$ of patients. No statistically significant difference was present between symptoms of different age groups $(\mathrm{p}>0.05)$.Table-III

Table- I : Demographic features of Schizophrenia cases $(n=50)$.

\begin{tabular}{|l|c|c|c|}
\hline Attributes & Category & Number & $\mathbf{\%}$ \\
\hline \multirow{4}{*}{ Age in years } & Up to 15 & 07 & 14.0 \\
& 16 to 29 & 30 & 60.0 \\
& 30 to 39 & 09 & 18.0 \\
& $>40$ & 04 & 08.0 \\
\hline \multirow{2}{*}{ Sex } & Male & 27 & 54.0 \\
& Female & 23 & 46.0 \\
\hline \multirow{3}{*}{ Marital status } & Married & 23 & 46.0 \\
& Unmarried & 23 & 46.0 \\
\multirow{2}{*}{ Religion } & Other & 04 & 08.0 \\
\hline \multirow{2}{*}{ Habitat } & Muslim & 45 & 90.0 \\
& Non-Muslim & 05 & 10.0 \\
\hline \multirow{4}{*}{ Education } & Urban & 25 & 50.0 \\
& Rural & 25 & 50.0 \\
\hline \multirow{3}{*}{ Social status } & Illiterate & 02 & 04.0 \\
& Primary & 05 & 10.0 \\
& Secondary level & 31 & 62.0 \\
& Higher & 12 & 24.0 \\
\hline \multirow{2}{*}{ Occupation } & Low & 15 & 30.0 \\
& Middle & 21 & 42.0 \\
& High & 14 & 28.0 \\
\hline
\end{tabular}

Table-II: Percentage distribution of presentation by age.

\begin{tabular}{|c|c|c|c|c|c|c|}
\hline \multirow[b]{2}{*}{ *Presentation } & \multicolumn{5}{|c|}{ Age in years } & \multirow[b]{2}{*}{$\begin{array}{c}\mathbf{p} \\
\text { value }\end{array}$} \\
\hline & $\begin{array}{c}<15 \\
(n=7)\end{array}$ & $\begin{array}{c}16-29 \\
(n=30)\end{array}$ & $\begin{array}{l}30-39 \\
(n=9)\end{array}$ & $\begin{array}{c}>40 \\
(n=4)\end{array}$ & $\begin{array}{c}\text { Total } \\
(\mathrm{n}=\mathbf{5 0})\end{array}$ & \\
\hline Delusion of reference & 71.4 & 70.0 & 66.7 & 70.0 & 70.0 & $\mathrm{p}>0.05$ \\
\hline Persecutory delusions & 57.1 & 80.0 & 77.8 & 70.0 & 76.0 & - \\
\hline Grandiose delusions & 14.3 & 13.3 & 0.0 & 0.0 & 10.0 & - \\
\hline Somatic delusions & 14.3 & 6.7 & 11.1 & 0.0 & 08.0 & - \\
\hline $\begin{array}{l}\text { Delusion about } \\
\text { possession of thought }\end{array}$ & 42.8 & 46.7 & 33.3 & 25.0 & 42.0 & $\mathrm{p}>0.05$ \\
\hline Auditory hallucination & 71.4 & 80.0 & 44.4 & 50.0 & 70.0 & $\mathrm{p}>0.05$ \\
\hline $\begin{array}{l}\text { Visual or other } \\
\text { hallucinations e.g., } \\
\text { gustatory, olfactory }\end{array}$ & 57.1 & 53.3 & 44.4 & 25.0 & 50.0 & $\mathrm{p}>0.05$ \\
\hline
\end{tabular}

*Multiple responses shows that in both sexes persecutory delusions were highest $(78 \%)$, the second being auditory hallucinations $(70 \%)$. Delusion of reference, delusion of persecution and delusion of control or possession were present more in males $(81 \%, 85 \%, 56 \%$ respectively) than of females (48\%, 70\%, 26\% respectively). Auditory hallucination and somatic delusions were present more in female $((78 \%, 13 \%$ respectively) than that of male $(63 \%, 07 \%$ respectively). Analysis revealed that delusion of reference, grandiose delusions, delusion of control possession of thought were significantly high among the male patients compared to female patients $(\mathrm{p}<0.05)$, but no statistically significant difference was observed with other symptoms $(\mathrm{p}>0.05)$.

Table- III: Percentage distribution of presentation by sex.

\begin{tabular}{|c|c|c|c|c|}
\hline \multirow[b]{2}{*}{ *Presentation } & \multicolumn{2}{|c|}{ Sex } & \multirow[b]{2}{*}{$\begin{array}{c}\text { Total } \\
(\mathbf{n}=\mathbf{5 0})\end{array}$} & \multirow[b]{2}{*}{$p$ value } \\
\hline & $\begin{array}{c}\text { Male } \\
(\mathrm{n}=27)\end{array}$ & $\begin{array}{c}\text { Female } \\
(n=23)\end{array}$ & & \\
\hline Delusion of reference & 81.5 & 47.8 & 66.0 & $\mathrm{p}<0.01$ \\
\hline Persecutory delusions & 85.2 & 69.6 & 78.0 & $\mathrm{p}>0.05$ \\
\hline Grandiose delusions & 22.2 & 0.0 & 12.0 & $\mathrm{p}<0.04$ \\
\hline Somatic delusions & 7.4 & 13.0 & 10.0 & $\mathrm{p}>0.05$ \\
\hline $\begin{array}{l}\text { Delusion of control } \\
\text { possession of thought } \\
\text { (insertion, withdraw, } \\
\text { broadcasting) }\end{array}$ & 55.6 & 26.1 & 42.0 & $\mathrm{p}<0.03$ \\
\hline Auditory hallucinations & 63.0 & 78.3 & 70.0 & $\mathrm{p}>0.05$ \\
\hline $\begin{array}{l}\text { Other hallucinations } \\
\text { (visual, gustatory, and } \\
\text { olfactory) }\end{array}$ & 40.7 & 56.5 & 48.0 & $\mathrm{p}>0.05$ \\
\hline
\end{tabular}

*Multiple responses

Table-IV: Percentage distribution of presentation by level of education.

\begin{tabular}{|l|c|c|c|c|c|}
\hline \multirow{2}{*}{ *Presentation } & \multicolumn{5}{|c|}{ Level of Education } \\
\cline { 2 - 6 } & $\begin{array}{c}\text { Illiterate } \\
(\mathbf{n = 2})\end{array}$ & $\begin{array}{c}\text { Primary } \\
\mathbf{( n = 5 )}\end{array}$ & $\begin{array}{c}\text { Secondary } \\
\mathbf{( n = 3 1 )}\end{array}$ & $\begin{array}{c}\text { Higher } \\
\mathbf{( n = 1 2 )}\end{array}$ & $\begin{array}{c}\text { Total } \\
(\mathbf{n = 5 0 )}\end{array}$ \\
\hline $\begin{array}{l}\text { Delusion of } \\
\text { reference }\end{array}$ & 100.0 & 60.0 & 67.7 & 66.7 & 68.0 \\
\hline $\begin{array}{l}\text { Persecutory } \\
\text { delusions }\end{array}$ & 100.0 & 40.0 & 83.9 & 75.0 & 78.0 \\
\hline $\begin{array}{l}\text { Grandiose } \\
\text { delusions }\end{array}$ & 0.0 & 0.0 & 12.9 & 16.7 & 12.0 \\
\hline $\begin{array}{l}\text { Somatic } \\
\text { delusions }\end{array}$ & 50.0 & 0.0 & 12.9 & 08.3 & 12.0 \\
\hline $\begin{array}{l}\text { Delusion of } \\
\text { possession } \\
\text { of thought }\end{array}$ & 0.0 & 20.0 & 32.3 & 75.0 & 42.0 \\
\hline $\begin{array}{l}\text { Auditory } \\
\text { hallucinations }\end{array}$ & 50.0 & 60.0 & 67.7 & 83.3 & 70.0 \\
\hline $\begin{array}{l}\text { Visual and other } \\
\text { hallucinations } \\
\text { e. g, gustatory, } \\
\text { olfactory }\end{array}$ & 0.0 & 60.0 & 48.5 & 50.0 & 48.0 \\
\hline
\end{tabular}

*Multiple responses 
Table-IV shows that persecutory delusions and auditory hallucinations were highest in all educational groups respectively $78 \%$ \& $70 \%$. Delusion of reference and non auditory hallucinations constitutes $68 \%$ \& $48 \%$ respectively. Delusion of control and possession was $42 \%$. The lowest rate was grandiose and somatic delusion $(12 \%)$.

Table-V: Percentage distribution of presentation by marital status.

\begin{tabular}{|c|c|c|c|c|c|}
\hline \multirow[b]{2}{*}{ *Presentation } & \multicolumn{4}{|c|}{ Marital Status } & \multirow[b]{2}{*}{ p value } \\
\hline & $\begin{array}{c}\text { Married } \\
(\mathrm{n}=\mathbf{2 3})\end{array}$ & $\begin{array}{c}\text { Unmarried } \\
(\mathrm{n}=\mathbf{2 3})\end{array}$ & $\begin{array}{l}\text { Other } \\
(n=4)\end{array}$ & $\begin{array}{c}\text { Total } \\
(\mathrm{n}=50)\end{array}$ & \\
\hline $\begin{array}{l}\text { Delusion of } \\
\text { reference }\end{array}$ & 78.3 & 65.2 & 100.0 & 74.0 & $\mathrm{p}>0.05$ \\
\hline $\begin{array}{l}\text { Persecutory } \\
\text { delusions }\end{array}$ & 82.6 & 69.6 & 75.0 & 80.0 & $\mathrm{p}>0.05$ \\
\hline $\begin{array}{l}\text { Grandiose } \\
\text { delusions }\end{array}$ & 0.0 & 17.4 & 50.0 & 12.0 & - \\
\hline \begin{tabular}{|l|} 
Somatic \\
delusions
\end{tabular} & 08.7 & 08.7 & 25.0 & 10.0 & $\mathrm{p}>0.05$ \\
\hline $\begin{array}{l}\text { Delusion of } \\
\text { control/possession } \\
\text { of thought }\end{array}$ & 30.4 & 47.8 & 75.0 & 42.0 & $\mathrm{p}>0.05$ \\
\hline $\begin{array}{l}\text { Auditory } \\
\text { hallucination }\end{array}$ & 56.5 & 78.3 & 100.0 & 70.0 & $\mathrm{p}>0.05$ \\
\hline $\begin{array}{l}\text { Visual, Other } \\
\text { hallucinations } \\
\text { e. g gustatory, } \\
\text { olfactory }\end{array}$ & 39.1 & 65.2 & 25.0 & 50.0 & $\mathrm{p}>0.05$ \\
\hline
\end{tabular}

*Multiple responses

Table-V shows that persecutory delusion (80\%), delusion of reference $(74 \%)$ and auditory hallucinations were more prevalent than grandiose and somatic delusion. Persecutory delusion and delusion of reference were more in married group. Delusion of control and possession and hallucination were more common in unmarried group than those with married group. Analysis found no statistically significant difference between married and unmarried patients ( $\mathrm{p}>0.05)$.

Table-VI shows that delusion of reference (80\%) was highest in respect of occupation especially those of

Table-VI: Percentage distribution of presentation by occupation

\begin{tabular}{|l|c|c|c|c|}
\hline \multirow{2}{*}{ *Presentation } & \multicolumn{3}{|c|}{ Occupation } & \\
\cline { 2 - 5 } & $\begin{array}{c}\text { Unemployed } \\
(\mathbf{n}=\mathbf{3 6})\end{array}$ & $\begin{array}{c}\text { Employed } \\
(\mathbf{n}=\mathbf{1 4})\end{array}$ & $\begin{array}{c}\text { Total } \\
(\mathbf{n}=\mathbf{5 0})\end{array}$ & p value \\
\hline Delusion of reference & 77.8 & 85.7 & 80.0 & $\mathrm{p}>0.05$ \\
\hline Persecutory delusions & 72.2 & 92.8 & 78.0 & $\mathrm{p}>0.05$ \\
\hline Grandiose delusions & 11.1 & 00.0 & 08.0 & - \\
\hline Somatic delusions & 05.6 & 07.1 & 06.0 & - \\
\hline $\begin{array}{l}\text { Delusion of control/ } \\
\text { possession of thought }\end{array}$ & 41.7 & 42.9 & 42.0 & $\mathrm{p}>0.05$ \\
\hline Auditory hallucination & 77.8 & 57.1 & 72.0 & $\mathrm{p}>0.05$ \\
\hline $\begin{array}{l}\text { Visual \& other } \\
\text { hallucinations } \\
\text { e. g gustatory, olfactory }\end{array}$ & 58.3 & 35.7 & 52.0 & $\mathrm{p}>0.05$ \\
\hline
\end{tabular}

*Multiple responses employed (85.7\%). Delusion of persecution (78\%) and auditory hallucination (72\%) was also higher. Both auditory and non-auditory hallucinations were more common $(72 \%, 52 \%$ respectively) in unemployed group most of whom are female. Analysis revealed no statistically significant difference between unemployed and employed patients ( $\mathrm{p}>0.05)$.

Table-VII shows persecutory delusions being highest (76\%) and auditory hallucination was the next (68\%). The

Table-VII: Percentage distribution of symptom presentation by habitat

\begin{tabular}{|l|c|c|c|c|}
\hline \multirow{2}{*}{$*$ Presentation } & \multicolumn{3}{|c|}{ Habitat } & \multirow{2}{*}{ p value } \\
\cline { 2 - 4 } & $\begin{array}{l}\text { Urban } \\
(\mathbf{n = 2 5})\end{array}$ & $\begin{array}{l}\text { Rural } \\
(\mathbf{n}=\mathbf{2 5})\end{array}$ & $\begin{array}{l}\text { Total } \\
(\mathbf{n}=\mathbf{5 0})\end{array}$ & \\
\hline Delusion of reference & 68.0 & 60.0 & 64.0 & $\mathrm{p}>0.05$ \\
\hline Persecutory delusions & 72.0 & 80.0 & 76.0 & $\mathrm{p}>0.05$ \\
\hline Grandiose delusions & 16.0 & 08.0 & 12.0 & $\mathrm{p}>0.05$ \\
\hline Somatic delusions & 12.0 & 08.0 & 10.0 & $\mathrm{p}>0.05$ \\
\hline $\begin{array}{l}\text { Delusions of control } \\
\text { possession of thought }\end{array}$ & 48.0 & 36.0 & 42.0 & $\mathrm{p}>0.05$ \\
\hline Auditory hallucination & 64.0 & 72.0 & 68.0 & $\mathrm{p}>0.05$ \\
\hline $\begin{array}{l}\text { Visual \& other hallucinations } \\
\text { e. g gustatory, olfactory }\end{array}$ & 64.0 & 36.0 & 50.0 & $\mathrm{p}<0.05$ \\
\hline
\end{tabular}

*Multiple responses

least was the percentage of grandiose and somatic delusion, respectively $12 \%$ and $10 \%$. Persecutory delusions and auditory hallucination were more in rural setting, where as delusion of reference and delusion of control/possession of thought and non auditory hallucination were more in urban setting. Analysis found that no statistically significant difference was between urban and rural patients ( $p>0.05)$, except visual and other hallucinations e.g. gustatory, olfactory which were significantly high among the urban patients $(\mathrm{p}<0.05)$.

Table-VIII shows, persecutory delusions highest (76\%) was the commonest presentation followed by auditory

Table-VIII: Percentage distribution of presentation by religion.

\begin{tabular}{|c|c|c|c|c|}
\hline \multirow[b]{2}{*}{ *Presentation } & \multicolumn{3}{|c|}{ Religion } & \multirow[b]{2}{*}{ p value } \\
\hline & $\underset{(n=45)}{\text { Muslim }}$ & $\begin{array}{c}\text { Non- } \\
\text { muslim } \\
(n=5)\end{array}$ & $\begin{array}{c}\text { Total } \\
(n=50)\end{array}$ & \\
\hline Delusion of reference & 64.4 & 80.0 & 66.0 & $\mathrm{p}>0.05$ \\
\hline Persecutory delusions & 77.8 & 60.0 & 76.0 & $\mathrm{p}>0.05$ \\
\hline Grandiose delusions & 11.1 & 00.0 & 10.0 & $\mathrm{p}>0.05$ \\
\hline Somatic delusions & 13.3 & 00.0 & 12.0 & $\mathrm{p}>0.05$ \\
\hline $\begin{array}{l}\text { Delusions of control/ } \\
\text { possession of thought }\end{array}$ & 42.2 & 40.0 & 42.0 & $\mathrm{p}>0.05$ \\
\hline Auditory hallucination & 66.7 & 100.0 & 70.0 & $\mathrm{p}>0.05$ \\
\hline $\begin{array}{l}\text { Visual \& other hallucinations } \\
\text { e. g gustatory, olfactory }\end{array}$ & 53.3 & 20.0 & 50.0 & $\mathrm{p}>0.05$ \\
\hline
\end{tabular}

*Multiple responses

hallucination (70\%), delusion of reference $(66 \%)$, nonauditory hallucination (50\%), delusion of control/possession of thought $(42 \%)$. Persecutory delusion and non auditory hallucination was higher in Muslims and where as delusion of reference and auditory hallucination was higher in non-Muslims. Analysis 
revealed no statistically significant difference between Muslim and non-Muslim patients ( $\mathrm{p}>0.05)$.

Table- IX shows that around $81 \%$ of middle class of patients have persecutory delusions. Among the all classes on average persecutory delusion was also

Table- IX: Percentage distribution of presentation by socioeconomic condition.

\begin{tabular}{|c|c|c|c|c|c|}
\hline \multirow[b]{2}{*}{ *Presentation } & \multicolumn{4}{|c|}{ Socioeconomic condition } & \multirow[b]{2}{*}{$p$ value } \\
\hline & $\begin{array}{c}\text { Low } \\
(n=15)\end{array}$ & $\begin{array}{c}\text { Medium } \\
(n=21)\end{array}$ & $\begin{array}{c}\text { High } \\
(\mathrm{n}=14)\end{array}$ & $\begin{array}{c}\text { Total } \\
(n=50)\end{array}$ & \\
\hline Delusion of reference & 53.3 & 76.2 & 64.3 & 68.0 & $\mathrm{p}>0.05$ \\
\hline Persecutory delusions & 66.7 & 81.0 & 78.9 & 76.0 & $\mathrm{p}>0.05$ \\
\hline Grandiose delusions & 13.3 & 09.5 & 14.3 & 12.0 & $\mathrm{p}>0.05$ \\
\hline Somatic delusions & 06.7 & 04.8 & 21.4 & 10.0 & $\mathrm{p}>0.05$ \\
\hline $\begin{array}{l}\text { Delusions of control/ } \\
\text { possession of thought }\end{array}$ & 26.7 & 42.9 & 50.0 & 40.0 & $\mathrm{p}>0.05$ \\
\hline Auditory hallucination & 66.7 & 66.7 & 78.6 & 70.0 & $\mathrm{p}>0.05$ \\
\hline $\begin{array}{l}\text { Visual \& other hallucinations } \\
\text { e. g. gustatory, olfactory }\end{array}$ & 46.7 & 42.9 & 71.4 & 52.0 & $\mathrm{p}>0.05$ \\
\hline
\end{tabular}

*Multiple responses

commonest in all group. Low and middle class in Bangladeshi culture constitutes most of the patients. Among them auditory and non auditory hallucinations were highest in higher social classes but persecutory delusion and delusion of reference were higher more in low \& middle class. Analysis revealed no significant difference in economic classes $(\mathrm{p}>0.05)$.

\section{Discussion}

This study was a hospital based cross sectional study to ascertain the demographic correlates of schizophrenia as well as patterns of common symptom presentation in Bangladeshi cultural perspective. It was found that $54 \%$ of the patients were male and $46 \%$ were female. This observation coincides with the study of other workers who observed schizophrenia to be more common in male than female ${ }^{2,4}$.

Patients in this study belong to age from 14 to 45 years, though majority of them were adolescent or young adults. About $60 \%$ of the patients belonged to the age group 16 to 29 years. These findings are consistent with those reported by Sadock ${ }^{2}$.

The equal distribution of both married and unmarried in this study implies that marriage, though considered as a strong bondage and support, has no protective role. Divorce rate $(8 \%)$ is not conclusive whether separation or divorces was precipitated it or it is the effect of disease process. Study also reflects that $42 \%$ were of middle class and $28 \%$ were from lower class that coincides with social causation hypothesis and drift hypothesis ${ }^{6-9}$.

In this study both the urban and rural frequencies were equal $(50 \%)$ in number which is consistent with observation of other study where different workers observed that the risk of schizophrenia may be greater amongst those born or brought up in poor urban areas ${ }^{10,11}$. In this study based on SCID, the most frequent presenting symptom irrespective of demographic variables was persecutory delusion presented in $76 \%$ of all age groups. It corresponds to WHO survey where the percentage of delusion of persecution was $64 \%{ }^{14,15}$.

The next frequent symptom was auditory hallucination (70\%) that also conforms with WHO survey in 1973 where the rate was $74 \%$. Delusion of reference occupies the third position in being about $70 \%$ which also correspond with the survey rate (70\%). Visual and other hallucination rate found in this study was $50 \%$. All these frequencies are consistent with all cross cultural studies of hallucination ${ }^{14-16}$. Delusion of control and/or possession of thought especially thought insertion was more frequent approximately $42 \%$. The least frequent symptoms were somatic delusion (10\%), grandiose delusions (12\%) which also conforms in survey by other worker ${ }^{17}$.

It was also evident from the above study that the average percentage of persecutory and auditory hallucination was more in the late onset (more than 40 years) cases than that of early onset cases (below 15 years) which also conforms with the study of other workers where late onset cases showed more hallucination and delusions and less thought disorder than early onset cases ${ }^{16,17}$.

\section{Conclusion}

Presentation of patients varies from individual to individual but a few regularly recurring patterns could be identified. Individually the positive symptoms were less common than the negative symptoms. Thought disturbance included ideas of reference and various kinds of delusions. Delusion of persecution was commonest in Bangladeshi patients followed by delusion of reference and thought insertion. Auditory hallucinations were particularly common and a significant number of patients with schizophrenia also manifested visual hallucinations. Other types of hallucinations were particularly absent or rare. It now may be concluded that this study might have been able to create a baseline normative value in Bangladeshi cultural setting and would facilitate and generate interest for future studies, especially on areas not focused in this study. Future epidemiologic work in schizophrenia should use multisided prospective long term studies.

\section{References}

1. Thomus H M. Early detection and intervention of schizophrenia: rationale and research. British Journal of Psychiatry 1998; 172 (33):3-6. 2. Sadock BJ, Sadock VA. Comprehensive text book of psychiatry. 7th ed. London: Lippincott. Williams \& Wilkins; 2000: p.1096, 1113-1116, 1172-1175, 1194.

3. Gerstein PC. Schizophrenia: last updated [online]. 2004. [2004 Jan 7]. Holyoke medical centre, American academy of emergency medicine.

4. Diagnostic and Statistical Manual of Mental Disorders. 4th ed. Washington D.C: American Psychiatric Association; 1994.

5. Gelder M, Mayou R, Cowen P. Shorter Oxford Textbook of Psychiatry. 4th ed. Oxford: Oxford University Press; 2001.p. 329-334,350-362.

6. Cornblatt B. Hillside study of risk and early detection in schizophrenia. British Journal of Psychiatry 1998; 172 (33): 26-32.

7. Freedman R. Drug Therapy: Schizophrenia. New England Journal of Medicine 2003; 349:1738-49.

8. Chowdhuary AKMN, Alam MN, Ali SMK. Dasher Kandi Project Study: Demography, Morbidity and Mortality in a rural area of Bangladesh. Bangladesh Medical Research Council Bulletin 1981; 7 (1): 22-9. 
9. Goldberg EM, Morrison SL. Schizophrenia and social class. British Journal of Psychiatry 1963; 109: 785-802.

10. Faris REL, Dunham IW. Mental disorders in urban areas. Chicago: Chicago University Press; 1939. p.10-20.

11. Murphy HBM. Migration, culture and mental health. Psychological Medicine 1977;1 7: 677-84

12. Paykel ES. Contribution of life events to causation of psychiatric illness. Psychological Medicine 1978; 88: 245-53.

13. Forrest AD. Phenomenology and course of Schizophrenia. London: Churchill Livingstone; 1975:210-250.
14. International Classification of Diseases. 10th ed. Geneva: World Health Organization; 1987.

15. Sprtzer RL, Williams JB, Gibbon M. Structured Clinical Interview for DSM-III-R-Non-Patient Version. Newyork: State Psychiatric Institute. Bionetrics Research Department; 1987:80-92.

16. Murray R, Hill P, McGuffin P. The Essentials of Postgraduate Psychiatry. 3rd ed. Cambridge: Cambridge University Press; 1999. p.290.

17. Carpenter W. Report of the international pilot study of schizophrenia. Geneva: World Health Organization 1973; 01:20-90. 